\title{
Truth is Beauty, Beauty is Truth the Philosophy of John Keats Selected Odes
}

Jolly Bhattacharjee

Assistant Professor

Dayanand Brijendra Swarup (P.G.) College

Dehradun, Uttarakhand, India

jollybhattacharjee33@gmail.com

DOI: https://doi.org/10.24113/ijellh.v9i4.10995

Abstract

Life can never be completely free of problems and pain. This is perhaps because no two people think alike, work alike or have similar taste. Problems and pain will be there when two persons live. So there are bounds to be differences and judgements born there of and create disharmony and conflicts. The natural inclination of human mind to get rid of pain and problems of life wanders for a different world. The romantic poet John Keats philosophically searched for such a place and wanted to escape. And escaping into the world of imagination helped him to get rid of pain and problems of life and discovers anything true is beautiful as beauty dwells in truth. Manifestation of god in all the objects of nature magnetically attracts Keats's mind as it serves as a therapy to contemplate in the serene and isolated space he sought for. Human being and Nature are interrelated, meaning the harmonious unity of Man and Nature are interrelated as both assume qualities of the other as they born and die, ashes go into the lap of Mother Nature as the very essence of human being, the structure is made up of the elements of Nature. The serene, calm and quiet Nature provides a kind of nourishment 
to Keats' mind to discover the beauty, provides him joy and it is a truth. Longing of every soul is to be away from the problems of life.

Keywords: Escape, Problem, Life, Beauty, Truth

Introduction:

John Keats is one of the Romantic poets in English Literature who discovered truth in beauty through imagination. As a romantic poet, his poetry is full of imagination, love, pain, immortality, escapism. Art is the creation of beauty and romantic poet unveils the art which is mystic and beautiful.

According to the great critic, Walter Pater, "the romantic element in literature consists in the addition of the quality of strangeness to the quality of beauty, which is present in all works of art."

There is a grain of truth in the idea of the apparent insignificance of mundane life. Everyday life is a routine, recedes unnoticed into the background of human experience, and it appears to be trivial. What excitement can be generated in cooking, buying, washing can be derived from the enjoyment can be derived from drudgery of these chores. With such images in mind, many philosophers have observed that the everyday work symbolises some of the most alienating features of human life

The universal fact that something is repeated in everyday in practical life makes it dull, mundane, boring. Mental happiness is the product of habitual right thinking and it will cause the flowers of peace, joy and serenity to bloom wherever we go. Therefore, cultivate the will to be unafraid create own mental sunshine. Those who renounce the fruits of their actions and submit themselves completely to the divine will, arrive at the final termination of the cyclical life process to enjoy eternal bliss in perfect union with the god head. The 
tradition of seeking union with god through loving commitment is referred to as bhakti or devotion. Escaping into the world of imagination is what the natural yearning of the soul to forget the trivialities, pain and problems of life. John Keats, the romantic poet wants to escape from the shackles of life and seeks joy, wants to lose his identity and forget himself and his own existence and discovers a joy in the Nightingale's song. "Fade far away, dissolve and quite forget What thou among the leaves lostst never known the weariness, the fever, and the fret" John Keats like other romantic poets discovers escape in the past. His extraordinary imaginative power, penetrate deep into Nature and its silence. His writings are loaded by sensualities, emotions, passion, excitement, love and pain, though he was an escapist of reality yet he talks concerning reality and for farfetched vision. In his Odes, imagination is used as a strong mental device to avoid the grievances of life. Most of his poetry deals with the theme for quest of beauty, but pain, adventure, love, chivalry $\&$ joy are also some of his themes. Therefore this paper tries to focus Keats's imagination used as a intellectual device through some of his selected Odes, Keats express his feelings through Ode to a Nightingale.

My heart aches, and a drowsy numbness pains

My sense, as though of hemlock I had drunk,

Or emptied some dull opiate to the drains

One minute past, and Lethe-wards had sunk:

'Tis not through envy of thy happy lot,

But being too happy in thine happiness

Ode to a Nightingale is a personal poem that describes Keats's journey into the state of negative capability. Keats revealed in his writing an understanding of all things possessed beauty and he explores this beauty in the middle of pain and suffering and in identifying and subtly understanding that which is beautiful allows one to become more acquainted with truth Keats's journey into the state of negative capability and the wholesome idea of exquisiteness 
are the idiosyncratic characteristics of Keats's poetry alone. Anything which is beautiful is discovered as truth by Keats, Nature attracts the poet and his imagination transforms everything into a serene and a silent aura which is beautiful. The immense pleasure which is derived from Nature takes him into an exuberant state of mind and he discovers it a beautiful experience as it has a factor of truth in it, beauty becomes his religion and makes him forget all the harsh realities of life. Beauty is truth as explored by Keats and is one of the hallmarks of his poetry. In the poem Ode on a Grecian the feeling is expressed. 'Beauty is truth, truth beauty -that is all we know on earth, and all we need to know. If we delve deep into Keats's poetry it is revealed that the truth and imagination exists in reality and juxtaposes the mortality of man with the immortality of art, leads us to understand it is not the way of escaping from the realities of life, but to seek pleasure among troubles of the world. A critic Rossetti beautifully explains the philosophy of Keats.

In the Ode the axiom is 'Beauty is truth, truth beauty' which pairs with and even transcends 'A thing of beauty is a joy forever'. It is put forward as the message of the sculptured Grecian Urn to man thus propounded as being of universal application. It amounts to saying - Any beauty which is not truthful (if any such there be), and any truth which is not beautiful (if any such there be) are of no practical importance to mankind in their mundane conditions, but in fact there are none such; for, to the humans mind and truth are one and the same thing. Keats's perception and 'thought' is crystallised into this axiom as the sum and substance of wisdom for man, and he has bequeathed into us to ponder over itself and to lay to heart as the secret of his writings.

Ode to a Nightingale is an extraordinary composition of John Keats. It wonderfully reveals how brilliantly he deals with the opposite aspects of life e.g. pleasure and pain, the imaginary and the real, mortal and immortal etc. The Ode is an expression of spontaneous feelings rising in the heart of the poet listens to the singing of the Nightingale. The immense 
joy which was felt by the poet transports him into a state of sleep and numbness as is created by the drinking of hemlock. The poet imagines that the bird lives in a beautiful place and is spell bounded by its melodious song, but suddenly his pleasure turns into a kind of pain. He yearns to escape from the mundane world into the heavenly world of the bird. The poet is desperate to escape the world of people getting old, dying and a never ending chain of miseries into the enchanting world of the Nightingale. The poet's soul doesn't want beauty to fade away and flew into the world of his imagination. Keats flies into the world of infinity through the song of the bird and explores the deeper philosophy of human soul which dwells in this world of miseries in realty, but seeks for an escape into the beautiful world of imagination which has a factor of truth in it according to Keats. This mystical and amazing experience of Keats is so similar with Tagore and has a universal appeal.

You came sometime at dawn

You touched me and left smiling

Someone pushed aside my door of

Sleep and left that message

Waking up

I saw

That my eyes filled with tears

It seemed to me

That the sky whispered in my ear

It seemed to me

That my whole body was filled with songs

It seemed to me

Bent low with dew

Had blossomed out like a worship flower 
That my heart had left the life river shore

And had gone off to a boundless land.

The everyday is whatever form is all that mortal world have. It is its very inescapability, its ability to suck human into a daily grind, to deny them virtually everything, they need or want, to turn them into a bundle of frustrations and problems that might compel them to rebel against, a war or revolt is not needed here to imagine the relief we might experience when released from the pain of everyday living in this materialistic mortal world and seeks a free immortal world which is explored by Keats in the song of the Nightingale. In the 'Ode to a Nightingale' immortality is glimpsed in the birds effortless singing and the charismatic song had a deep impact on the poet's mind and stimulated with immense pleasure and aspiration of a blissful eternal life, the poet's exquisite craving to get rid of the frustrations, problems of mortal world to the immortal life of tranquillity and excellence has a universal appeal and is also seen in the works of William Wordsworth, too a worshipper of Nature, too, who explores the spiritual dimensions of beauty through his poems, In his poem Tintern Abbey, expresses the similar painful ordeal that he has passed through a painful ordeal, of mental crisis in the absence of Nature, but after years revisiting the Wye gives relief to his mind and it provides a close communion with Nature. He experiences a spiritual exaltation in all the objects of Nature and explores them as symbols of eternity that is beautiful and has a factor of truth in his exploration. The experience which impresses his mind is expressed:

Five years have past; five summers, with the length

of five long winters! and again I hear

These waters, rolling from then mountain-springs

With a soft inland murmur-once again

Do I behold these steep and lofty cliffs 
That on a wild secluded scene impress

Thoughts of more deep seclusion; and connect.

A factor of beauty is joy forever, the moving principle of life and loved beauty in myriad forms and shapes, in the song, in the flower, in the sky or in a work of art. His aesthetic vision grows intellectually and his imagination transforms the world of senses into the world of eternity, and brings a confluence of spiritual exaltation. In the poem Ode on a Grecian Urn the poet's exploration of the relationship between imagined beauty and the harsh reality of everyday experience is depicted aesthetically. Immortality is to be discovered in the stillness and silence of classical Greek art and sculpture, Keats praises the Urn as a 'Unravish'd' bride of quietness; and the imagination created must be true as its beautiful for him:

Heard melodies are sweet, but those unheard

Are sweeter; therefore, ye soft pipes, play on;

Not to the sensual ear, but more endeare'd,

Pipe to the spirit ditties of no tone:

Fair youth, beneath the trees, thou canst not leave

Thy song, nor ever can those trees be bare;

The pictorial narratives are beautiful than words and the urn is depicted as a beautiful piece of art and a mystery to a casual observer, but Keats might had an insight to explore the beauty which is true to him. Keats's imagination reveals Urn is a mystic art and is superior to reality, which soothes the mind and soul. The silent scenes in the Urn are timeless, and speak across generations and protect the scenes of the Urn from the impermanence of mortal life. Art is permanent and human life is temporary, the Urn will be as it is forever, the poet cannot 
hear the music, but he could imagine and feel that music and enjoy. Imagination transports him into the divine enjoyment of music.

Keats tries to explore beauty in the natural world, providing a relief from the miseries of mundane life. His intense human sense explores the beauties of the external world, is transformed into poetry by his wonderful imagination. According to Keats, whatever is beautiful must be true. Beauty and truth are inseparable and sides of the same coin. Keats conveys the message living in this mortal life, we can enjoy beauty accepting life in all forms. As famous conclusion of his poem: Beauty is truth, truth beauty- that is all Ye know on earth, and all ye need to know 


\section{Works Cited}

S.Sen. John Keats. Odes, Hyperion, The Fall of Hyperion and other poems. A Critical Evaluation. New Delhi: Unique Publishers. 1976. ISBN: 978-81-8357-599-7 Code:1.12.1, P-

P-125 .

$\mathrm{P}-124$.

P-111.

$\mathrm{P}-123$.

Tagore Rabindranath.Gitimalya (Garland of songs) Translated by BrotherJames. The University Press Limited. Translation copyright Brother James, 1984

S.Sen. Selected Poems William Wordsmith A Critical Evaluation, at Unique Publishers(I) Pvt. Ltd. ISBN: 978-81-8357-593-5, Code: 1:16

S.Sen. John Keats. Odes, Hyperion, The Fall of Hyperion and other poems. A Critical Evaluation. New Delhi: Unique Publishers. 1976. ISBN: 978-81-8357-599-7 Code:1.12.1, P-110.

P-111

Jana, A., 2021. KEATS’ BEAUTY- SENSE AND SENSUOUSNESS. [Blog] Arghya Jana Literature Guide, Available at: <https://arghyajanaliteratureguide.blogspot.com/2016/01/keats-beauty-sense-andsensuousness.html> [Accessed 25 January 2021]. 